\title{
Youtuber: A New Work Conception
}

Giovani Paganini ${ }^{1} \quad$ Joel Haroldo Baade ${ }^{2 *} \quad$ Adelcio Machado dos Santos ${ }^{3} \quad$ Sandra Mara Bragagnolo ${ }^{4}$ 1.School of Management, Alto Vale do Rio do Peixe University, Rua Amadeo Rossi, 800. Caçador (SC) 89.500000, Brazil

2.Postgraduate Program in Development and Society, Alto Vale do Rio do Peixe University, Rua Amadeo Rossi, 800. Caçador (SC) 89.500-000, Brazil

3.Postgraduate Program in Development and Society, Alto Vale do Rio do Peixe University, Rua Prof. Egídio Ferreira, $n^{\circ}$ 271, Apto. 303, Florianópolis (SC) 88090-699, Brazil

4.School of Management, Alto Vale do Rio do Peixe University, Rua Amadeo Rossi, 800. Centro - Caçador (SC) 89.500-000, Brazil

\begin{abstract}
The work and worker perspective marks various times of history, several studies are applied along periods and always seek to improve the concepts and techniques of work. In view of the evolution of concepts and the fast technological revolution, this article aims to analyze the profile and understand the work of a YouTuber compared to traditional forms of work. For this, a brief survey of the concepts of traditional management models is done; characteristics of YouTubers as workers are raised; traditional forms were compared with the conception of work on the YouTube platform. This is a descriptive study with qualitative data analysis. A semi-structured interview was applied to 15 YouTubers who agreed to participate in the research. Thus, it was possible to investigate information and describe characteristics of this new way of working. It was found that YouTubers have common characteristics, especially that they are self-taught, had low investments in equipment and have no employment. Comparisons of traditional work characteristics with YouTubers were made and it was found that this form of work does not maintain significant similarities with the Taylor, Fayol and Ford management models, approaching, in some aspects, Toyotism, such as: flexible production, adaptability and being qualified, multifunctional, flexible and adaptable.
\end{abstract}

Keywords: Work, YouTubers, Characteristic of the worker.

DOI: $10.7176 /$ RHSS/11-4-05

Publication date: February $28^{\text {th }} 2021$

\section{Introduction}

The term work has its origin from the Latin Tripalium, which comes from an instrument of torture used by farm owners who punished workers who did not fulfill their obligations. Even in other languages, the meaning is rooted in suffering. This conception of work carries a burden in its genesis, causing the workers to lose their freedom and feel trapped in his work environment (WOLECK, 2002).

YouTube is a personalized content platform that allows users to upload their videos. In this channel, videos authored by the user and a list of videos from other channels that the user subscribes to are presented in a feed, according to their preference. It is also possible for other users to comment on the author's videos (YOUTUBE, 2011).

On the YouTube platform, there are more than 1.9 billion users connected who access the platform every month. What contributes to this data is that YouTube launched local versions in mor e than 91 countries and in up to 80 different languages, which covers $95 \%$ of internet users (YOUTUBE, 2019b, n.p).

The growth of YouTube channels with more than one million subscribers is identified, with an increase of $75 \%$ per year. Over the past five years, more than US\$ 2 billion has been paid to partners who generate revenue through Content ID claims (copyrighted materials that can be blocked from showing or allow the video to remain active with ads, generating revenue from advertising which is destined to copyright owners) (YOUTUBE, 2019b, $\mathrm{np})$.

The research is justified by the scarcity of studies related specifically to YouTubers as workers, mainly on characteristics and skills that these professionals need to develop. Some characteristics and skills to make a channel on the YouTube platform were identified on the platform itself, where there are short courses to manage and create a channel (YOUTUBE, 2019b, n.p).

According to the YouTube platform itself (2019b, n.p), its audience is young (aged between 18 and 34) and has an average of 1.9 billion visits per month. These data instigate this study so that it is possible to survey and analyze the way the YouTuber professional works and manages his time.

This study, then, aims to analyze the profile and understand the YouTuber work compared to traditional forms of work. As specific objectives, the study seeks to characterize the traditional management models; to present the content of the interviews with YouTubers; to raise the characteristics of the YouTuber worker; and to establish a parallel between traditional models and new conceptions of work. 


\section{Work conceptions and industrial revolutions}

In the early days of civilization, workers produced their goods manually, the strength of man is what moved production, products were exclusive and produced in a limited way. With that, traditional models of management studied the way men worked, in various ways, such as Taylor's study of times and movements; Fayol's hierarchical structure and workplace organization; the search for total quality, which Toyotism teaches; and Ford's production line, among others, in a way that facilitated workers not to waste time (CATANI, 1985; RIBEIRO, 2017; FAYOL; DORES, 1978).

With the advent of Industrial Revolutions, conceptions of work evolved, as in the First Revolution, when the steam engine brought mass production; in the Second Revolution, which brought on the assembly line; and, also, with the Third and the Fourth Industrial Revolution. The latter, also known as the digital revolution, causes workers to qualify and acquire new skills, such as interpersonal relationships and awakening of creativity. However, what differentiates the Fourth from the Third Industrial Revolution is the interaction of different technologies, not only physical but also digital and biological (WOLECK, 2002; SCHWAB, 2019).

The Fourth Industrial Revolution brought with it the existence of products and services, which, before monopolized, now come at low cost. Before, to order a taxi, a telephone was charged with specific fees according to each local legislation, however, smartphone applications emerged in which it is possible to call a transport service for people, at a lower cost and at the consumer's free choice, which makes life easier (SCHWAB, 2019).

With the Fourth Digital Revolution, discussions about the characteristics and skills that new workers need to acquire become more and more relevant. However, even with all the relevance of new forms of work, over the last ten years, an issue has been raised in an increasingly relevant way: the new characteristics of YouTuber professionals. Among these characteristics is the generation of new sources of income through the platform for YouTubers, significantly increasing the number of users connected to the site, generating more views than traditional forms of media (WESTENBERG, 2016).

The challenges encountered in the world of work have undergone a significant decline. According to Schwab (2019), the main beneficiaries are providers of intellectual capital and innovators. It is also possible to note that the effects of automation and artificial intelligence have been leaving jobs at risk for the next two decades, something that will impact jobs for much of the middle class. Given this scenario, it can be seen that new skills and characteristics will be crucial for new forms of work to be created.

It is noticed that workers are influenced by the reality in which they live. It is a context in constant change, with an increasingly fast pace. This new environment brings new characteristics to the workers, with more flexible hours and continuous learning as a form of competitive advantage. With globalization, geographical barriers are disappearing (BAUMAN, 1999).

The ability to change and develop skills will be needed for the new worker. With this, new forms of work have been developed, more flexible, for example, working from home, or autonomously, for digital platforms, such as YouTube, producing content independently (SOUZA; SANTOS; FREITAS, 2018; SANTOS, 2017).

Studies on the effects of automation and artificial intelligence indicate that countries such as the United States, Japan, the United Kingdom and Germany have jobs at risk for the next two decades. Between 35\% and $47 \%$ of occupations are being replaced by automation, as in the electronics industry, construction, among others; and Artificial Intelligence will impact banks, offices and other areas, such as public service, thus eliminating the employment of a large part of the middle class (MAGALHÃES; VENDRAMINI, 2018).

Analysts have an optimistic outlook for these changes, as they believe that new occupations and business opportunities may be part of the future, employing those who were at the mercy of technology, however, new skills will be needed (MAGALHÃES; VENDRAMINI, 2018).

The workers suffer from the influence of social events. The reality in which they live translates into a term created to define the post-Cold War world, the acronym VUCA which stands for Volatile, Uncertain, Complex and Ambiguous (SANTOS, 2017; SOUZA; SANTOS; FREITAS, 2018).

The term Vuca has been used by companies to refer to the environment that is disorderly, turbulent and transmutes too fast. Situations that previously had little impact, now reflect on the whole society, due to its interdependence and globalization. Characteristics of the new business environment make it increasingly necessary to deal with collaborative networks and learning communities. This creates the need for flexible working hours and continuous learning. Who can adapt to these characteristics has greater competitive advantage (SOUZA; SANTOS; FREITAS, 2018).

Geographical, sectorial and business barriers are disappearing, and these modifications will require capacity for change, adaptation, evolution and continuous renovation, without losing the objectives of results, demanding more and more complex and adaptive thinking skills (SOUZA; SANTOS; FREITAS, 2018).

The current socioeconomic context has shown that new forms of work are being developed, becoming more flexible. For example, there are home offices, which are progressively becoming more common with the evolution of the internet, emerging, then, the remote worker, who performs the work for a company in a non- 
face-to-face manner (SOUZA; SANTOS; FREITAS, 2018; SANTOS, 2017).

Working by projects emerges, in which work is done on demand, and not continuously. And works on digital platforms, such as Facebook, Instagram and YouTube, do everything from marketing to producing content independently (SOUZA; SANTOS; FREITAS, 2018; SANTOS, 2017).

People create their own businesses for different reasons, most small businesses are not innovative, as the goal of entrepreneurs is to achieve financial and professional independence. The majority of new ventures are created from own resources, usually savings, but in more advanced stages, fundraising from external sources becomes interesting for the expansion of the business (BESSANT; TIDD, 2009).

\section{Youtube and youtubers platform - content producers}

The creators of the YouTube platform are former employees of the e-commerce site PayPal, Chad Hurley and Jawed Karim, officially launched in June 2005 in the United States. At that time, among several online video platforms, YouTube tried to eliminate barriers such as bandwidth for video streaming, and low technical knowledge of users, thus having greater sharing of videos on the internet (BURGESS; GREEN, 2009).

Burgess and Green (2009) state that the business of YouTube is to provide a convenient and functional way for sharing videos online and for users to attract an audience to the platform. These conveniences for users translate into a new cultural environment:

YouTube has its place within the long history and uncertain future of changing media, cultural participation policies and growth of knowledge. Clearly, it is both a symptom and an agent of cultural and economic transitions that are in some way linked to digital technologies, the internet and the more direct participation of consumers (BURGESS; GREEN, 2009, p. 32, our translation).

Online content distribution platforms have been changing the social context, YouTube reveals that content produced by amateurs, without commercial purposes, attracted many viewers (SNICKARS; VONDERAU, 2009).

The YouTube platform goes beyond online content, the communication provided by it helps people mobilizing for greater causes, for example, the mobilization of part of the Brazilian population during the heavy rains that hit the country in 2008. It is not only about technology, but also about connection between people. One is influenced by online social networks every day, news is seen in real time, YouTube generates about ten hours of video content and information every minute, from different areas (COSTA; MIRANDA, 2019).

The YouTube platform has a structure that facilitates video interaction, allows users to upload videos directly from the webcam on their computer or choosing a video file stored on it, allowing communication with subscribers on their channel and with other YouTubers (COSTA; MIRANDA, 2019).

The term YouTubers refers to content creators, who record their videos on the most diverse subjects and manage their channels in the virtual environment hosted on the World Wide Web. They are the main responsible for contents published on the YouTube platform. Most YouTubers are young and, in their channels, one can find a variety of videos on the most diverse themes, from tutorials to personal subjects, from video games to humor, music and a multitude of contents (BERZOSA, 2017).

The YouTuber concept happens on the internet, in which people collaborate with content, disseminate and promote debates with users. This forms a culture among participants, characteristic of the easy access to the internet, in which works are shared and knowledge is exchanged between ordinary users and professionals, forming an opinion together (SERRANO; HERRERO, 2016).

The term content producer has been used since 2005 and refers to various forms of media produced by the public, except for paid professionals. To be considered a content producer, it is necessary to publish on accessible sites, for example, on social networks, excluding private messages, such as electronic mail or WhatsApp. Still, it is necessary to have creativity for the content produced, because just copying a content, without any modification, is a mere copy and does not characterize production and innovation (WESTENBERG, 2016).

Social media can be described as mobile technology, based on the internet, which have platforms where users can share, discuss, modify and co-create content. What is seen happening on the YouTube platform is that teenagers use their smartphones and do not remember or did not live in a time before online social networks. These young people make up the so-called Generation Z, which includes those born in the late 1990s until the 2010s. These content consumers are connecting less and less to traditional TV programs and consuming more digital content (WESTENBERG, 2016).

YouTubers monetize their channel as a source of income, but YouTube does not create content or inform what content to create, but rather takes care of viewers, content creators and advertisers. As a YouTube partner, the user can earn money from the platform, however, it is necessary to meet strict requirements (YOUTUBE, 2019a, n.p). The ways to make money with YouTube are described in Table 1. 
Table 1. Ways to Make Money with YouTube

\begin{tabular}{|l|l|}
\hline Ad revenue: & Revenue is earned for displaying image, overlay and video ads. \\
\hline Channel memberships: & $\begin{array}{l}\text { Members make monthly payments in exchange for special } \\
\text { benefits offered by the YouTuber. }\end{array}$ \\
\hline Merch shelf: & $\begin{array}{l}\text { Fans can see and buy the official products of the channel posted } \\
\text { on the watch pages. }\end{array}$ \\
\hline Super Chat: & $\begin{array}{l}\text { Fans pay for their messages to appear highlighted in a live stream } \\
\text { chat. }\end{array}$ \\
\hline $\begin{array}{l}\text { YouTube Premium } \\
\text { revenue: }\end{array}$ & $\begin{array}{l}\text { Part of a YouTube Premium user's subscription fee is received } \\
\text { when they watch your content. }\end{array}$ \\
\hline
\end{tabular}

Source: Adapted from YOUTUBE (2019a)

Videos recorded by YouTubers are usually amateurs, recorded in their rooms, schools and friends' houses, with main objective of exposing their opinions to society without direct intervention by people who may restrict manifestations of beliefs, theories, judgment and criticism that they wanted to expose. However, these young people reach millions of views and become celebrities, which led their profiles to certain standards, promoting the professionalization of these new stars (COSTA; MIRANDA, 2019).

YouTube (2019a) delimits some rules for the channel to be monetized, according to Table 2. In addition to the number of subscribers and views, each resource presented in Table 1 has qualification requirements. Analysts decide whether the channel can activate certain features and whether they meet the requirements of the YouTube platform. These requirements exist for two main reasons: to meet legal needs in the areas where resources are available; and reward good content creators (channels are constantly evaluated to ensure that they comply with the platform's legal policies) (YOUTUBE, 2019a).

Table 2. Minimum qualification requirements to activate revenue generation.

\begin{tabular}{|c|c|}
\hline $\begin{array}{l}\text { Forms of } \\
\text { monetization }\end{array}$ & Requirements \\
\hline Ad Revenue & $\begin{array}{l}\text { Be at least } 18 \text { years old or have a legal guardian older than that age } \\
\text { who can manage the payments via Google AdSense; } \\
\text { Create content that meets the appropriate content guidelines for } \\
\text { advertising. }\end{array}$ \\
\hline $\begin{array}{l}\text { Channel } \\
\text { memberships: }\end{array}$ & $\begin{array}{l}\text { Be at least } 18 \text { years old; } \\
\text { Have more than } 30 \text { thousand subscribers; } \\
\text { Have no community guidelines strikes. }\end{array}$ \\
\hline Merch shelf: & $\begin{array}{l}\text { Be at least } 18 \text { years old; } \\
\text { Have more than } 10 \text { thousand subscribers; } \\
\text { Have no community guidelines strikes. }\end{array}$ \\
\hline Super Chat: & $\begin{array}{l}\text { Be at least } 18 \text { years old; } \\
\text { Live in a country/region where Super Chat is available. }\end{array}$ \\
\hline $\begin{array}{l}\text { YouTube Premium } \\
\text { revenue: }\end{array}$ & Create content watched by YouTube Premium subscribers. \\
\hline
\end{tabular}

Source: Adapted from YouTube (2019a)

What gives the channel originality is the content published and classified by themes, and its production is based on the public, as people aged between 10 and 25 are migrating from traditional TV to YouTube, where they can watch the programming they want, whenever they want, therefore, there is more public interaction (BERZOSA, 2017).

According to Berzosa (2017), the main themes accessed are: games, entertainment, music, beauty, fashion and fitness, technology, experiments, crafts and tutorials. The reason for producing content is the direct interaction with people, through comments on social networks or in videos themselves and, thanks to this, there 
are more and more followers, attracting the interest of brands that want to sponsor YouTubers.

\section{Methodological delimitations}

The research seeks to fill a gap in knowledge about YouTubers, as a job conception, with the aim of analyzing the profile and understanding YouTuber work compared to traditional ways of working.

The approach of this study is qualitative, being characterized as descriptive and exploratory research.

Data collection and analysis of YouTubers' testimonials is done by non-probabilistic sampling for convenience. The survey was carried out with professionals who have an active YouTube channel, regardless of the number of subscribers.

A positive response was obtained from 15 YouTubers, who sent responses to the semi-structured interview. However, about 50 channels were selected and contacted through social networks, email and telephone, but no response was received.

The questions involved the activities and themes related to the daily lives of YouTubers, in order to identify characteristics of their work activity. The observation of functioning of the YouTube platform also served to support the analyses presented here.

The analysis of the data to look for characteristics of YouTubers and their similarities was done through interviews via email, audio and video, due to the fact that the YouTubers are in several locations of Brazil and other countries. Respondents have a channel on YouTube and some have not yet monetized it. One of them is by choice, as their goal is to produce quality content, without receiving money for it, which can be compared with traditional forms of management, as voluntary work. Other respondents still use the channel as a second source of income, however, channels with higher number of subscribers belong to YouTubers who have their main income through the YouTube platform.

\section{Results and discussion}

In this section, the characteristics of work and worker are presented for the main traditional management models: Taylorism, Fordism, Fayolism and Toyotism. This characterization is necessary in order to achieve another objective of this research, which is to establish a comparative parallel between YouTubers and workers of these traditional models. Table 3 shows a comparison between the models of work organization of the main theorists.

Table 3. Comparison between work and worker

\begin{tabular}{|c|c|c|c|c|}
\hline & Taylorism & Fordism & Fayolism & Toyotism \\
\hline Work & $\begin{array}{l}\text { - Based on studies of } \\
\text { times and movements } \\
\text { - Simple functions } \\
\text { - Work execution } \\
\text { patterns } \\
\text { - Eliminate waste of } \\
\text { human labor }\end{array}$ & $\begin{array}{l}\text { - Based on assembly } \\
\text { line } \\
\text { - Continuous flow } \\
\text { - Simple functions } \\
\text { - Work control } \\
\text { - Mass production }\end{array}$ & $\begin{array}{l}\text { - Seeks to remove } \\
\text { obstacles that hinder } \\
\text { the workers } \\
\text { - Division of work } \\
\text { - Interests of the } \\
\text { company above the } \\
\text { interests of the worker }\end{array}$ & $\begin{array}{l}\text { - New production model } \\
\text { - Multi-functional teams } \\
\text { - Flexible production } \\
\text { - Total quality } \\
\text { - Lean working practices }\end{array}$ \\
\hline Wo & $\begin{array}{l}\text { - Obedient } \\
\text { - Low creativity } \\
\text { - Works for money } \\
\text { - Poor qualification } \\
\text { - Job dependent }\end{array}$ & $\begin{array}{l}\text { - High turnover } \\
\text { - Higher salary to win } \\
\text { a worker } \\
\text { - Mass consumption } \\
\text { - Disciplined worker } \\
\text { - Little or no } \\
\text { intellectual capacity }\end{array}$ & $\begin{array}{l}\text { - Disciplined worker } \\
\text { - Division of work } \\
\text { - Low intellectual } \\
\text { knowledge } \\
\text { - Little or no } \\
\text { qualification }\end{array}$ & $\begin{array}{l}\text { - Adaptable } \\
\text { - Qualified } \\
\text { - Schooled } \\
\text { - Multifunctional } \\
\text { - Adaptable } \\
\text { - Interested in the } \\
\text { company's objectives }\end{array}$ \\
\hline
\end{tabular}

Source: TAYLOR, 1997; CATANI, 1985; LIPIETZ, 1989; FAYOL, DORES, 1978; RIBEIRO, 2017; ALVES, 2010; THOMAZ, 1992.

Changes in the way of working and in the profile of workers reflect economic and social changes, together with development of industry and management. In order to establish characteristics of YouTubers, interviews were conducted with people who have channels on the YouTube platform. The subjects of this research are briefly presented:

Interview 1 was conducted with Gustavo Quintanilha, 26 years old, Rio de Janeiro - RJ, Brazil. The Guto TV 
channel has approximately 336 thousand subscribers and is aimed at entertainment and humor.

Interview 2 was conducted with Vinicius Hozara, 37 years old, Rio de Janeiro - RJ, Brazil. The Meu Carro Lifestyle channel has content about cars, such as reviews, tips, among others, with approximately 290 thousand subscribers. He joined the YouTube platform as an additional niche in his profession, as a producer of audiovisual content for over 11 years.

Interviewee 3, Jane Loures, did not reveal her age. She is from Juiz de Fora - MG, Brazil. Her channel is about cooking, where she shows sweet and savory recipes. She has experience in the kitchen of more than 50 years, which allowed her to support her children. The Jane Loures channel has approximately 1.3 million subscribers.

Interview 4 was conducted with Joana Borga, from Caçador - SC, Brazil, who maintains the Joana Borga channel, with approximately 490 subscribers, in order to teach crafts. She started her YouTuber career in 2019. Joana has a degree in Business Administration, an MBA in Marketing and started her career as a partner in a clothing store at the age of 19. As she always liked crafts and manual arts, in 2013, she sold the store and became a craftswoman.

Interview 5 took place with the channel Lightworkers - Trabalhadores da Luz, from Rio de Janeiro - RJ, Brazil. A member of the channel, who did not identify himself, says that the channel has approximately 115 thousand subscribers with the intention of sharing experiences.

Interview 6 was conducted with the Faell Vasc channel, from Jundiaí - SP, Brazil. With approximately 22,900 subscribers, the channel is the only one about gay dramaturgy in the world. When he started the channel on YouTube, he had to invest in an editing software, camera, memory card, lighting and sound.

Interview 7 was with the channel LipãoGamer, from Caçador - SC, Brazil, which has about 8 million subscribers and is about electronic games. Felipe started on YouTube in 2011.

Interview 8 was with the channel Nerd Show, by Renato and Bárbara, from Belo Horizonte - MG, Brazil, which has around 1.37 million subscribers. The focus of the channel are curiosities of the world. Renato says that the beginning of any job is very complicated, especially in a market that was still a little foggy.

Interview 9 was with Gretchen (Maria Odete Brito de Miranda Marques), from the Gretchen \& Você channel, with about 322 thousand subscribers, from Monaco. Gretchen is famous for several television appearances throughout her career and her channel is a diary of her personal life and opinions.

Interview 10 was with Rebecca Jackson, from the channel Minha Professora Gringa, from the United States, with about 251 thousand subscribers. Rebecca became famous for posting a video on the platform during her learning of the Portuguese language and, thus, her channel is about her trajectory in learning the Portuguese language.

Interview 11 was with Renan and Michele, from the Mundo Sem Fim channel. They are touring the world and sharing it on their channel, with around 103 thousand subscribers. They started in an amateur way. The channel was created to basically support a blog. Over time, their followers asked for better and more complete videos. So they decided to invest in a GoPro camera. From then on, they started making longer videos and the channel grew. Interview 12 was with Ricardo Molina, from the Ricardo Molina USA channel, which has approximately 141 thousand subscribers. Ricardo has five degrees and is a real estate agent in the USA. His channel gives tips for those who want to live and invest in Orlando.

Interview 13 was with the John Moonstone channel, which has approximately 119 thousand subscribers. John started his channel in 2006 without knowing that it was possible to monetize it. His intention was to show his work as a singer, without any pretense.

Interview 14 was with the Diário de um Autista channel, which has approximately 120 thousand subscribers. Marcos Petry reports that his work on YouTube started with music. It sparked the interest of many people who commented, encouraged and wanted new content every week. This engagement led Marcos to reflect on the little information that existed about autism. So, he thought about approaching the spectrum from the perspective of everyday life, sharing contents about inclusion.

Interview 15 was with the Carros com Camanzi, Camila $e$ Emílio channel. They have 417 thousand subscribers. Emílio is 71 years old and says that the channel's objective is to cover news from the automobile industry, events in the sector, among others.

In view of the interviews and observation of the dynamics of Youtube, it is understood that the platform has entered into a wide expansion due to the convenience it provides. Videos streamed can be accessed through a compatible device that has an internet connection, one can watch any available content, stop and watch it later, among other conveniences.

Table 4 shows the specific characteristics of the 15 interviewees. 
Table 4. Specific Characteristics of YouTubers

\begin{tabular}{|c|c|}
\hline Interviewed Channel & Characteristics \\
\hline 1 GutoTV & $\begin{array}{l}\text { - Tension for punishment or copyright lawsuit } \\
\text { - Challenge for competition with new channels } \\
\text { - Interaction with the public to define upcoming content } \\
\text { - Started as a hobby }\end{array}$ \\
\hline 2 Meu carro Lifestyle & $\begin{array}{l}\text { - Interaction with the public to define upcoming content } \\
\text { - Has his own creative company with employees for various functions } \\
\text { - Works about eight hours a day } \\
\text { - Work does not generate tension } \\
\text { - Continuous learning }\end{array}$ \\
\hline $\begin{array}{l}3 \text { Jane Loures - Canal de } \\
\text { Culinária }\end{array}$ & $\begin{array}{l}\text { - Started as a hobby } \\
\text { - Her son helps in editing the videos } \\
\text { - Schedules contents in advance } \\
\text { - Interaction with the public to define upcoming contents }\end{array}$ \\
\hline 4 Joana Borga & $\begin{array}{l}\text { - Interaction with the public } \\
\text { - Work does not generate tension } \\
\text { - Continuous learning }\end{array}$ \\
\hline \begin{tabular}{l|l}
5 & Lightworkers \\
Trabalhadores da Luz & -
\end{tabular} & $\begin{array}{l}\text { - Volunteer work } \\
\text { - Produces content every night } \\
\text { - Does not use YouTube as a source of income, it was decided not to monetize } \\
\text { the channel. } \\
\text { - The content has an informative purpose and is made for those who appreciate } \\
\text { their work } \\
\text { - Faces no challenges. } \\
\text { - It has an agenda, however, they do not follow to the letter, if there is any more } \\
\text { important content, it is given priority. } \\
\text { - Interaction with the public }\end{array}$ \\
\hline 6 Faell Vasc & $\begin{array}{l}\text { - Investment in equipment } \\
\text { - Recruits third parties to help in specific cases } \\
\text { - Scheduled content } \\
\text { - Interaction with the public to define upcoming content } \\
\text { - Started as a hobby } \\
\text { - Background in performing arts is used to record and edit videos. } \\
\text { - Has no criticism on the channel } \\
\text { - Gets partnerships for trips, recording the content in exchange for publicizing } \\
\text { the partner brand }\end{array}$ \\
\hline 7 LipãoGamer & $\begin{array}{l}\text { - Works } 10 \text { to } 12 \text { hours a day with content production } \\
\text { - Themes are based on the audience and the US YouTube platform. } \\
\text { - Continuous search for knowledge and quality equipment } \\
\text { - Subscribers look for Lipãogamer content, not a specific game } \\
\text { - Can work anywhere on the planet } \\
\text { - Interaction with the public } \\
\text { - Enjoys the recognition from subscribers both online and in person }\end{array}$ \\
\hline 8 Nerd Show & $\begin{array}{l}\text { - Started as a hobby } \\
\text { - Investment over time in better equipment } \\
\text { - Did all the work, over time, hired employees } \\
\text { - Did not have a defined work pace at the beginning, after some time, delimited } \\
\text { an average of eight hours a day, five days a week } \\
\text { - Has a background in Graphic Design } \\
\end{array}$ \\
\hline 9 Gretchen \& Você & $\begin{array}{l}\text { - Interaction with the public } \\
\text { - Work does not generate tension } \\
\text { - No content planning }\end{array}$ \\
\hline $\begin{array}{l}10 \text { Minha professora } \\
\text { Gringa }\end{array}$ & $\begin{array}{l}\text { - Interaction with the public } \\
\text { - Works } 50 \text { hours a week at flexible hours } \\
\text { - Generates a little tension because it is not a fixed income } \\
\text { - No content planning }\end{array}$ \\
\hline
\end{tabular}




\begin{tabular}{|l|l|}
\hline 11 Mundo sem fim & $\begin{array}{l}\text { - Started as a hobby } \\
\text { - No content planning } \\
\text { - Does not generate tension and seeks to meet the expectations of followers } \\
\text { - Challenge of getting good internet for not having a fixed workplace }\end{array}$ \\
\hline 12 Ricardo Molina USA & $\begin{array}{l}\text { - Interaction with the public } \\
\text { - Has another job besides being a YouTuber }\end{array}$ \\
\hline 13 John Moonstone & $\begin{array}{l}\text { - Started his work as a hobby } \\
\text { - Rarely reads comments } \\
\text { - Exposes his freedom of expression and art creation }\end{array}$ \\
\hline 15 Carros com Camanzi & $\begin{array}{l}\text { - Started the channel for informational purposes } \\
\text { - Has a support team just to answer and filter comments } \\
\text { - Interaction with the public }\end{array}$ \\
\hline & $\begin{array}{l}\text { - Interaction with the public } \\
\text { - Generates a little tension because it is not a fixed income } \\
\text { - Continuous search for knowledge and first quality equipment }\end{array}$ \\
\hline
\end{tabular}

Source: Research data (2019).

Then, in Table 5, there are recurring characteristics identified in the interviews with YouTubers:

Table 5. Recurring Characteristics of YouTubers

\begin{tabular}{|c|c|c|c|c|c|c|c|c|c|c|}
\hline$/=$ & 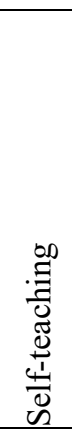 & 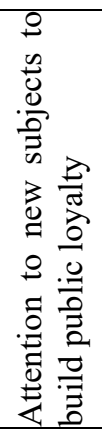 & 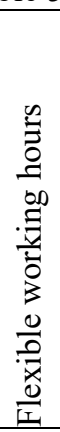 & 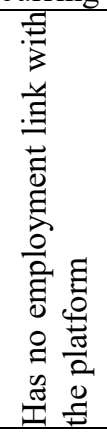 & 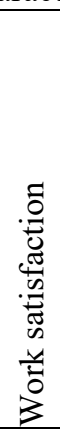 & 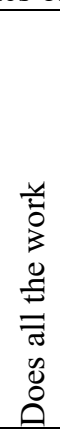 & 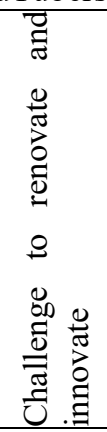 & 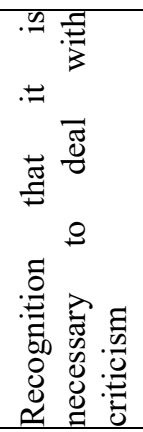 & 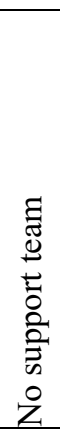 & 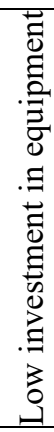 \\
\hline 1 & $X$ & $X$ & $\mathrm{X}$ & $X$ & $X$ & $\mathrm{X}$ & $\mathrm{X}$ & $X$ & & $X$ \\
\hline 2 & $\mathrm{X}$ & $X$ & & $X$ & $X$ & & & $X$ & & $X$ \\
\hline 3 & $\mathrm{X}$ & & & $X$ & $X$ & & & $\mathrm{X}$ & $X$ & $X$ \\
\hline 4 & $X$ & & $X$ & $X$ & $X$ & & & $\mathrm{X}$ & $X$ & $X$ \\
\hline 5 & $\mathrm{X}$ & $X$ & & $X$ & $X$ & & & & $X$ & \\
\hline 6 & $X$ & $X$ & & $X$ & & & $\mathrm{X}$ & $X$ & & $X$ \\
\hline 7 & $\mathrm{X}$ & $X$ & & $\mathrm{X}$ & $X$ & & $\mathrm{X}$ & $\mathrm{X}$ & $X$ & $\mathrm{X}$ \\
\hline 8 & $\mathrm{X}$ & $X$ & & $X$ & $X$ & $X$ & $X$ & $\mathrm{X}$ & & $\mathrm{X}$ \\
\hline 9 & $\mathrm{X}$ & & $X$ & $X$ & $X$ & $X$ & & $X$ & & $X$ \\
\hline 10 & $\mathrm{X}$ & & $X$ & $X$ & $X$ & $X$ & & $X$ & $X$ & \\
\hline 11 & $\mathrm{X}$ & & $X$ & $X$ & $X$ & & $X$ & $X$ & $X$ & $X$ \\
\hline 12 & $\mathrm{X}$ & & $X$ & $X$ & $X$ & $\mathrm{X}$ & & & $X$ & $X$ \\
\hline 13 & $\mathrm{X}$ & & $X$ & $X$ & $X$ & $X$ & & & $X$ & $X$ \\
\hline 14 & $X$ & & $X$ & $X$ & $X$ & & & & & $\mathrm{X}$ \\
\hline 15 & $\mathrm{X}$ & & $X$ & $X$ & $X$ & & $X$ & $X$ & & $\mathrm{X}$ \\
\hline
\end{tabular}

Source: Research data (2019).

Among the most common characteristics of YouTubers are self-education, attention to new subjects to retain the public, flexible working hours, not receiving help from others, as well as low or no investment in equipment at the beginning of the channel.

The challenge of keeping up to date and having to innovate in publications is recurrent. The characteristics of not having an employment relationship, learning to deal with criticisms and feeling satisfied with their work are also recurring.

It can be seen, through the data collected, that, in the age of internet, learning new skills becomes an easier task, as knowledge is available to anyone who has a device connected to the internet. According to the interviewees, it is possible to learn to edit, record, among other tasks associated with production of content on the platform itself.

It is inferred, from the testimonials of YouTubers, that a channel that is under development has no resources and only earns money for its content on the YouTube platform after reaching the requirements determined by it. For this reason, learning to "do everything" helps in consolidation, without generating costs, until the channel 
stabilizes and starts generating revenue.

Minimum investment to have a channel makes the professionals able to start their work as a content producer only with equipment they already have, because with a cell phone that records videos, with audio, it is already possible to send them to the platform through internet connection, which reveals a fundamental characteristic of YouTubers: not needing a specific location or equipment for recording videos and also having flexible working hours.

The YouTube platform does not generate direct jobs with content producers, after reaching the necessary requirements to monetize their channel, the YouTuber has the option to monetize or not. If the option is to monetize the channel, after meeting the requirements, the amount is calculated by the platform and is sent from its headquarters (California, USA) to the worker's checking account. In this process, the amount must be converted from dollar to the national currency, and documentation must be sent to the bank that will receive the amount from the platform, so that it can be passed on to YouTuber.

Interaction with the public, most of the time, comes from comments. Those who have an account on the YouTube platform can comment on videos, however, many profiles are fake and aim to demotivate the YouTuber, with insults and offensive words, however, it is found in the interviews that positive comments and affection of subscribers outweigh negative criticism.

Satisfaction of YouTubers is identified in all interviews, the content producers make their channel in their own way, defining which theme they will make their next video about, where it will be made, and also producing content in advance, so that if any unforeseen event happens, subscribers will not be left without content. This allows them to create expectations about their followers' receptivity; and results, which are usually positive, feed the feeling of satisfaction.

\section{Comparison of characteristics of traditional models with the new work conceptions}

The way of working observed on the YouTube platform does not match perfectly with any of the traditional models of work organization. YouTubers differ from the Taylorist model. Taylor has his theory based on studies of times and movements, an obedient employee with low creativity and little qualification. YouTubers are free to work wherever they want, are not dependent on fixed machinery to produce or machine movements to work, but rather use their creativity to produce attractive content for their followers. It also appears that the majority of YouTubers are self-taught, that is, it cannot be compared with Taylor's theory, in which the employee had low qualifications and their intelligence was underestimated.

When YouTubers are compared with Ford's theory, in which there is an assembly line, continuous flow, simple functions and mass production, it is perceived that, for content production, mass production is not necessary, after all, a content produced reaches any user of the platform who watches the video. The continuous flow can be a characteristic compatible with YouTubers, since it is necessary to feed the subscribers of the channel so that they do not migrate to other platforms.

Simple functions are not characterized as similarity between Fordism and YouTubers, who performs most of the roles in the channel, from the script to the editing of the vídeos. YouTubers are also not disciplined as Fordism determines, as there are no fixed hours for the production of content.

The characteristics of Fayol's theory are: division of labor, interests of the company are above the interests of the worker, disciplined work, low intellectual knowledge and little or no qualification.

None of these characteristics is part of the work conception analyzed in this research. YouTubers do all the work. Nine of the fifteen respondents $(60 \%)$ report that they decide on their working hours and produce the content that is most viable to them. It is noticeable that YouTubers have intellectual knowledge and qualification in the area in which they produce.

When comparing YouTubers to Toyotism, there are some similarities, such as flexible production, in which YouTubers produce their content at a viable time; and multifunctionality in content producers, as they generally do not have a support team. Adaptability can be another similar characteristic, since YouTubers follow the platform guidelines, which they need to adapt to.

When asked about the best thing about being a YouTuber, interaction with the public was the answer that came up the most, since, with the advent of the internet, interaction became easier. Before, it was necessary to gather people in some physical place to have interaction. Today, only an equipment connected to the internet is needed. YouTubers also highlight the fact that who watches the channel is who subscribe, that is, who identify with the content that is made available there.

The investment in equipment for most of the interviewees was made after obtaining some stability in the platform. At first, cell phones and other materials that they already had in their home were used.

The similar characteristics of both being qualified, multifunctional, flexible and adaptable are perceived. The differentiation is the absence of a labor relationship, making it an unstable situation for those who have the YouTube platform as their only source of income. 


\section{Final considerations}

This study analyzes traditional management models based on field research with YouTubers, professionals who produce content to disseminate in a virtual environment. They have some specific knowledge in an area, record it and make it available on the YouTube platform. What is perceived is that these professionals learned autonomously to use content production tools, such as editors of videos, sounds, images, among others.

The information brought by the YouTubers makes it possible to understand this new way of working, where the content producer, after reaching the necessary requirements for their channel, has the option of monetizing it, that is, earning money through the YouTube platform with what they produce.

YouTubers who chose not to monetize their channel were also identified, as they claim to do this as a hobby or for informational purposes. These channels can, by extension, be related to voluntary work, as they aim to help people without receiving financial value in return.

Through bibliographic research on traditional management models, some characteristics in common were identified among the workers from Taylorism, Fordism and Fayolism: low intellectual capacity, low or no professional qualification and job dependence, however, this view begins to change with Toyotism, which shows workers more aligned with the company's objectives, multifunctional teams, qualification for carrying out work, and schooling of the workers.

Common characteristics were identified among YouTubers. Some of them showed up in all or almost all respondents. The most present is that they are self-taught professionals, that is, they learn on their own effort, without taking courses or through teachers. The internet enabled the expansion of knowledge, where, with a quick search, one can find countless pages teaching how to do what they seek.

The satisfaction of working with what they like is another relevant characteristic, and what complements this are the flexible working hours, as YouTubers produce their content according to their schedules, with no fixed commitment.

When comparing the YouTuber professional with traditional management models, there is no perfect parallel, since YouTubers have no employment relationship, do not have a fixed workplace (although many have their recording studio, it is possible to broadcast live from a cell phone connected to the internet anywhere on the planet). The low intellectual capacity and low or no professional qualifications cannot be compared with YouTubers, which is self-taught and is always innovating.

The traditional management model that comes closest to YouTubers is Toyotism, which has some similar characteristics, they are qualified, multifunctional, flexible and adaptable. However, the labor relation occurs differently, because in Toyotism, workers are aligned with company's objectives; and YouTubers have no employment relationship with the platform.

As a limitation, the difficulty of respondents to adhere to the survey can be highlighted. Among the 50 YouTubers to whom a request to participate in the survey was sent, only 15 returned with interest. This represents 30\% response, an acceptance rate considered low compared to the attempts made by YouTubers' social media.

A suggestion for future work is the continuation of this research with more respondents in order to obtain more relevant characteristics about this new form of work, surveying the manners and amounts YouTubers earn for their work.

It is also possible to extend this research to other professions that are emerging, such as Uber, which is a transport service similar to taxi, however, workers of the app do not have employment relationships with the platform. It is also possible to collect data from startups, which are ideas sponsored by investors and put into practice, among other platforms.

\section{References}

ALVES, G. (2010). Toyotismo como ideologia orgânica da produção capitalista.

BAUMAN, Z. (1999). Globalização: as consequências humanas. Rio de Janeiro: Jorge Zahar.

BESSANT, J. \& TIDD, J. (2009). Inovação e empreendedorismo-3. Rio de Janeiro: Bookman.

BURGESS, J. \& GREEN, J. (2009). YouTube e a revolução digital. São Paulo: Aleph.

CATANI, A. M. (1985). O que é taylorismo. Revista de Administração de Empresas, 25 (4), 81-82.

COSTA, E. \& MIRANDA, R. D. (2019). Seleção Brasileira ou YouTuber. Revista Alterjor, 20 (2), $42-62$.

FAYOL, H. \& DORES, J. A. M. (1978). Administração industrial e geral: previsão, organização, comando, coordenação," controle". São Paulo: Atlas.

LIPIETZ, A. (1989). Fordismo, fordismo periférico e metropolização. Ensaios FEE, 10 (2), 303-335.

MAGALHÃES, R. \& VENDRAMINI, A. (2018). Os impactos da quarta revolução industrial. GV Executivo, 17 (1), 40-43.

RIBEIRO, A. L. (2017). Teorias da administração. São Paulo: Saraiva.

SANTOS, M. O. G. (2017). Contributo para uma reflexão sobre um mundo em mutação e sobre as tendências que o influenciam. Pensar o Futuro, Preparar a Mudança. Espírito Santo: Évora. 
SCHWAB, K. (2019). A quarta revolução industrial. Rio de Janeiro: Edipro.

SNICKARS, P. \& VONDERAU, P. (2009). The YouTube Reader. Lund: Kungliga biblioteket.

SOUZA, L. R. A., SANTOS, J. M. M. S. \& FREITAS, C. B. (2018). Reflexão sobre a dinâmica do "mundo vuca" e seu impacto na educação profissional a distância. São Paulo. Retrieved from: http://www.abed.org.br/congresso2018/anais/trabalhos/5036.pdf. Accessed: November 20. 2019.

TAYLOR, F. (1997). Administração científica. São Paulo: Atlas.

WESTENBERG, W. M. (2016). The influence of YouTubers on teenagers: a descriptive research about the role YouTubers play in the life of their teenage viewers. Master thesis. University of Twente.

WOLECK, A. (2002). O trabalho, a ocupação e o emprego: uma perspectiva histórica. Revista de Divulgação Técnico-científica do Instituto Catarinense de Pós-Graduação, 1, 33-39.

YOUTUBE (2011). YouTube. Retrieved, 27.

YOUTUBE (2019a). Como ganhar dinheiro com o YouTube. Retrieved from: https://support.google.com/youtube/answer/72857?hl=pt-R\&ref topic=9257989. Access: August 25. 2019a.

YOUTUBE (2019b). Youtube para imprensa. Retrieved from: https://www.youtube.com/intl/ptBR/yt/about/press/. Access: August 20. 2019. 